\title{
PW03-005 - NLRP3-Q705K monocytes do not produce more IL-1B
}

\author{
G Simon ${ }^{1 *}, \mathrm{~N}$ Busso ${ }^{1}$, A von Scheven-Gete ${ }^{2}$, I Moix ${ }^{3}$, M Morris $^{3}$, A So ${ }^{1}$, M Hofer $^{2}$ \\ From 7th Congress of International Society of Systemic Auto-Inflammatory Diseases (ISSAID) \\ Lausanne, Switerland. 22-26 May 2013
}

\section{Introduction}

PFAPA is a pediatric auto-inflammatory syndrome of unknown etiology, characterized by recurrent fever, aphthosis, pharyngitis and cervical adenitis. Dysregulated monocyte interleukin-1 beta (IL-1 $\beta$ ) secretion is thought to play an important role in fever flares. Recently, it was published that Thp1 cells (a monocytic cell line) transduced with the Q705K variant of NLRP3 increased IL$1 \beta$ secretion after alum (an adjuvant used in vaccines) stimulation.

\section{Objectives}

We hypothesized that monocytes isolated from healthy adults carrying the Q705K variant of NLRP3 secrete more IL-1 $\beta$ than monocytes from adults with a WT NLRP3 after ultra pure lipopolysaccharide (LPSup) stimulation.

\section{Methods}

Monocytes of six PFAPA families whereby only one of the two parents was carrying the Q705K variant were isolated by MACS and stimulated with LPSup. Levels of IL- $1 \beta$, TNF- $\alpha$ and IL- 6 produced by monocytes isolated from Q705K positive parents were compared to family members expressing WT NLRP3.

\section{Results}

The production of IL- $1 \beta$, TNF- $\alpha$ or IL- 6 is not significantly different between monocytes from Q705K positive and WT NLRP3 parents (Q705K NLRP3: $4583.7 \pm$ $2671.1,3110 \pm 2904.6$, and $49043.7 \pm 37257.9 \mathrm{pg} / \mathrm{ml}$; WT NLRP3: $3499.4 \pm 2946.7,935.6 \pm 1259.4$, and 45982 $\pm 18317.4 \mathrm{pg} / \mathrm{ml}$ respectively).

${ }^{1} \mathrm{CHUV} /$ Rhumatology, Lausanne, Switzerland

\section{Conclusion}

Our results show that the Q705K variant of NLRP3 do not lead to any modulation in cytokine production capacity following LPSup stimulation, as compared to WT controls.

\section{Disclosure of interest}

None declared.

\section{Authors' details}

${ }^{1} \mathrm{CHUV} /$ Rhumatology, Lausanne, Switzerland. ${ }^{2} \mathrm{CHUV} /$ Pediatrics, Lausanne, Switzerland. ${ }^{3}$ HUG / Service of Genetic Medicine, Geneva, Switzerland.

Published: 8 November 2013

doi:10.1186/1546-0096-11-S1-A231

Cite this article as: Simon et al:: PW03-005 - NLRP3-Q705K monocytes do not produce more IL-1B. Pediatric Rheumatology 2013 11(Suppl 1): A231.
Submit your next manuscript to BioMed Central and take full advantage of:

- Convenient online submission

- Thorough peer review

- No space constraints or color figure charges

- Immediate publication on acceptance

- Inclusion in PubMed, CAS, Scopus and Google Scholar

- Research which is freely available for redistribution
C Biomed Central
Full list of author information is available at the end of the article

() Biomed Central

(c) 2013 Simon et al; licensee BioMed Central Ltd. This is an Open Access article distributed under the terms of the Creative Commons Attribution License (http://creativecommons.org/licenses/by/2.0), which permits unrestricted use, distribution, and reproduction in any medium, provided the original work is properly cited. 